\title{
Kan man bli frisk av schizofreni?
}

\author{
Det går an å bli frisk av schizofreni, selv når dette defineres som stabil symptomfrihet og god sosial og \\ arbeidsmessig fungering i minimum 12 måneder. Ved vanlig behandling ser det ut som om ca. 15 \% vil til- \\ fredsstille disse kriteriene ti år etter behandlingsstart. Ved ekstra tidlig start av behandlingen øker antakelig \\ sjansen til det dobbelte.
}

Schizofreni er en alvorlig psykotisk lidelse. Felles for psykosene er at det foreligger en realitetsbrist: En som er psykotisk greier ikke å skille mellom fantasi og virkelighet, mellom hva som foregår inni ham og hva som skjer rundt ham. De vanligste symptomene er vrangforestillinger og hallusinasjoner. En vrangforestilling kan defineres som en ukorrekt og ukorrigerbar forestilling om den ytre virkelighet. Personen holder fast ved forestillingen til tross for at alle andre mener at den uomtvistelig er uholdbar. Hvis forestillingen deles av andre i personens subkultur, er det ikke rimelig å kalle det en vrangforestilling, selv om et overveldende flertall mener at den er uholdbar.

Hallusinasjoner er sansepersepsjoner som opptrer uten adekvat ytre stimulus. Personer med schizofreni vil ofte ha både vrangforestillinger og hallusinasjoner. Relativt mange vil ha vrangforestillinger uten hallusinasjoner, mens hallusinasjoner uten vrangforestillinger forekommer mye sjeldnere. Personer med mer alvorlige grader av schizofreni vil ikke sjelden ha bisarre vrangforestillinger. Det vil si forestillinger som folk flest vil se på som komplett umulige. Opplagte eksempler er at tyver hadde stjålet noen av ens indre organer uten å ha etterlatt seg noe spor. Det er imidlertid ikke lett å trekke noen sylskarp grense mellom bisarr og ikke bisarr, og selv blant fagfolk kan det være betydelig uenighet om hvorvidt en forestilling er bisarr eller ei.

Psykotiske symptomer skyldes svikt i hjernens funksjon. Ved schizofreni er årsaksforholdene kompliserte. Arv spiller en vesentlig rolle, men arven er sammensatt, antakelig ved samvirke av en rekke gener som forekommer relativt hyppig i befolkningen, men som hver for seg har en svak effekt. En uheldig kombinasjon av en rekke slike gener vil resultere $\mathrm{i}$ en sårbarhet $\mathrm{i}$ form av svekket kognitiv kapasitet, og svekket evne til å bearbeide sanseinntrykk og følelser. Denne sårbarheten gjør at personer med schizofreni lett blir overveldet av opplevelser, tanker og følelser. Som en pasient uttrykte det en gang: «Jeg får overflow på computeren.» Under uheldige omstendigheter vil belastningen overskride individets kapasitet i den grad at det oppstår psykotiske symptomer.

Det er betydelige individuelle variasjoner i hvor store belastninger som skal til for å utløse symptomene. Hos noen foreligger en så alvorlig sårbarhet at selv relativt små belastninger vil kunne utløse psykotiske symptomer. Hos andre, med mer velfungerende hjerne, vil det trengs sterke belastninger. Det er god grunn til å anta at schizofreni, slik som det er definert i moderne klassifikatoriske systemer, ikke er én sykdom, men flere. Selv om personer med schizofreni skulle ha relativt like symptomer, kan noen ha en reversibel funksjonssvikt, mens andre kan ha en mer permanent svikt i hjernefunksjonen. Schizofreni er blitt sammenliknet med gulsott: Sykdomsbildet kjennetegnes av typiske og slående symptomer, men det kan foreligge en rekke ulike grunnlidelser, som krever ulik behandling og har ulik prognose.

\section{«Med tidlig innsettende adekvat behandling er prognosen langt bedre enn vi tidligere trodde»}

Ved mer alvorlig hjerneaffeksjon vil det i tillegg være uttalte negative symptomer, som følelsesmessig tilbaketrekking og apati. Det er ting som tyder på at utvikling av negative symptomer kan være selvforsterkende, og at det derfor vil være viktig å komme til tidlig med behandling. For en god del pasienter kan tidlig intervensjon antakelig forhindre utviklingen av slike symptomer.

Det har vært en utbredt oppfatning at det ikke går an å bli bra av schizofreni. Dette gir seg utslag i uttrykk som «han er schizofren»), underforstått: Vedkommende er gal og vil fortsette å være det resten av livet. Dette bidrar til en stigmatisering som det ikke er grunnlag for. Med tidlig innsettende adekvat behandling er prognosen langt bedre enn vi tidligere trodde.

\section{Hva er det å bli frisk?}

Det er nødvendig å nyansere hva vi mener med å bli frisk. Vi kan i hvert fall skille mellom fire nivåer: $\AA$ greie seg utenfor institusjon; å være symptomfri; å fungere sosialt; å fungere i arbeidslivet.

Jeg vil i det følgende gi noen anslag for sannsynligheten for bedring på hvert av områdene. Anslagene bygger på TIPS-prosjektet: et prosjekt for tidligintervensjon ved psykose. I perioden 1997-2000 rekrutterte vi et representativt utvalg av pasienter med førstegangspsykose i Rogaland fylke, Ullevål sektor i Oslo og Midtsektor i Roskilde i Danmark. Pasientene er blitt fulgt opp i ti år. Anslagene er grove estimater, som bygger på de pasientene som ved inntak hadde schizofreni, schizofreniform lidelse eller schizoaffektiv lidelse. De som ønsker mer detaljert informasjon, henvises til artiklene i referanselisten (1-6).

Hospitalisering. Med adekvat behandling kan vi regne med at halvparten vil greie seg med under tre måneders sykehusopphold i løpet av det første året av sykdommen. $\mathrm{Ca}$. tre firedeler vil trenge under et halvt år, og bare ca. $10 \%$ vil trenge å være innlagt hele året. I de følgende ni neste årene vil en firedel greie seg helt uten sykehusopphold. Den neste firedelen vil bare trenge ett eller et par opphold, med samlet varighet på under tre måneder. Den tredje firedelen vil trenge en samlet tid i sykehus på 3-18 måneder. En liten gruppe, ca. $10 \%$, vil trenge å være hospitalisert mer enn halve tiden.

Symptomer. Å bli frisk av symptomene sine vil si at man ikke lenger har psykotiske symptomer som vrangforestillinger eller hallusinasjoner. Med moderne behandling vil halvparten oppnå det innen tre måneder etter behandlingsstart og innpå tre firedeler innen ett år (4). Bare for en mindre del (10-20\%) vil symptomene bli kroniske (5). For de fleste vil symptomfriheten bli avbrutt av perioder med tilbakefall, som regel i forbindelse med påkjenninger og/eller avbrudd i behandlingen. Men for flertallet vil symptomfrie perioder vare $i$ år om gangen. Hvis tilbakefall oppdages raskt og behandles adekvat, vil de kunne være kortvarige. I løpet av en tiårsperiode, kan vi regne med at $40 \%$ vil være symptomfrie minst $95 \%$ av tiden, ytterligere $20 \%$ vil være symptomfrie $>50 \%$, mens ca. $10 \%$ vil være kontinuerlig psykotiske.

Sosial fungering. Kontakten med venner ser ut til å være ganske stabil. Vel halvparten vil møte venner regelmessig (minst $2-3$ ganger per måned), mens ca. $10 \%$ vil være uten noen sosial kontakt.

Arbeid. Vel halvparten vil relativt raskt få uføretrygd, og vil bli varig mottakere. Snaut $30 \%$ vil være i deltidsarbeid, mens $15-20 \%$ vil være i fulltidsarbeid. 


\section{Kan man bli frisk av schizofreni?}

Konklusjonen blir at det går an å bli frisk av schizofreni, selv når dette defineres som stabil symptomfrihet og god sosial og arbeidsmessig fungering i minimum 12 måneder. Ved vanlig behandling ser det ut som om ca. $15 \%$ vil tilfredsstille disse kriteriene ti år etter behandlingsstart. Ved ekstra tidlig start av behandlingen øker antakelig sjansen til det dobbelte (5). I tillegg vil mange ha lange symptomfrie perioder. Imidlertid er det viktig å understreke at selv om de fleste personer med schizofreni er uten psykotiske symptomer mesteparten av tiden, vil en del være preget av følelsesmatthet og apati, og de fleste vil i stor grad bevare sin sårbarhet. Det kan gi seg utslag i en viss rigiditet, lav stresstoleranse og begrenset utholdenhet. De vil fortsatt ha lav toleranse for uklare og kompliserte situasjoner, og vil ha særlig store problemer med å tåle følelsesmessige spenninger og kritikk. Det vil komplisere samspillet med andre mennesker og gi problemer med å etablere nye kontakter. Derfor er de sårbare for kontaktbrudd, og har behov for trygge, stabile kontakter, ikke minst innen helsevesenet. En del vil greie seg uten medikamenter, men for mange kan det se ut som om livslang antipsykotikabehandling er vesentlig. De fleste vil ha spesifikke varselssymptomer som tegn på et truende tilbakefall. Det er viktig at den enkelte lærer å kjenne sine varselsignaler, og får muligheter for å redusere stimulusmengden.
I tillegg vil det være aktuelt å trappe opp vedlikeholdsbehandling med antipsykotika, eller å restarte slik behandling.

Det er samtidig viktig å understreke at arbeidskapasiteten til disse pasientene lenge har vært undervurdert. Det er nå godt dokumentert at mange av dem vil kunne være en betydelig ressurs i arbeidslivet (7). Det vil spare trygdeutgifter, samtidig som det å være i arbeid har en helsefremmende effekt. Men det forutsetter at forholdene legges til rette for dem, som for andre med funksjonshemning.

\section{Svein Friis}

svein.friis@medisin.uio.no

Avdeling for forskning og utvikling

Klinikk psykisk helse og avhengighet

Oslo universitetssykehus, Aker

Svein Friis (f. 1945) er spesialist i psykiatri. Han er professor ved Institutt for klinisk medisin, Universitetet i Oslo og overlege ved Avdeling for forskning og utvikling, Klinikk psykisk helse og avhengighet, Oslo universitetssykehus. Han har arbeidet med klinisk psykiatrisk forskning siden tidlig i 1970-årene, og er sammen med professor Thomas McGlashan leder for TIPS-prosjektet (Tidlig intervensjon ved psykoser).

Forfatter har fylt ut ICMJE-skjemaet og oppgir ingen interessekonflikter.
Litteratur

1. Melle I, Larsen TK, Haahr U et al. Reducing the duration of untreated first-episode psychosis: effects on clinical presentation. Arch Gen Psychiatry 2004: 61: 143-50.

2. Melle I, Johannesen JO, Friis S et al. Early detection of the first episode of schizophrenia and suicidal behavior. Am J Psychiatry 2006; 163: 800-4.

3. Larsen TK, Melle I, Auestad B et al. Early detection of first-episode psychosis: the effect on 1-year outcome. Schizophr Bull 2006; 32: 758-64.

4. Simonsen E, Friis S, Haahr U et al. Clinical epidemiologic first-episode psychosis: 1-year outcome and predictors. Acta Psychiatr Scand 2007; 116: $54-61$.

5. Hegelstad WT, Larsen TK, Auestad B et al. Longterm follow-up of the TIPS early detection in psychosis study: effects on ten-year outcome. Am J Psychiatry 2012; .e-publisert 8.3.2012.

6. Friis S. Hva har vi lært av TIPS-prosjektet? I: Rund $B R$, red. Schizofreni. Stavanger: Hertevig Akademisk, 2011: 317-32

7. Davis LW, Lysaker PH. Therapeutic alliance and improvements in work performance over time in patients with schizophrenia. J Nerv Ment Dis 2007; 195: $353-7$

Mottatt 1.3. 2012 og godkjent 8.3. 2012. Medisinsk redaktør Erlend Hem. 